\title{
Building networks among info pros
}
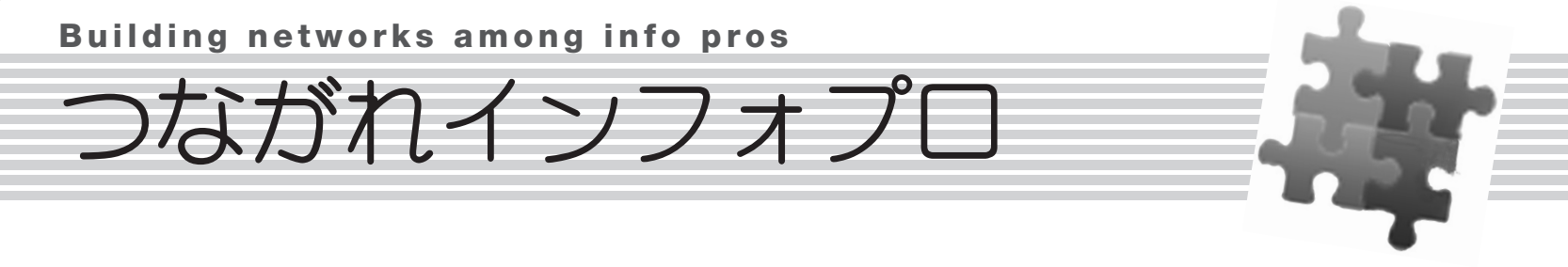

第 19 回

佐々木 文彦（富士フイルム知財情報リサーチ株式会社 調査分析ユニット）

情報管理. 2015, vol. 58, no. 1, p. 53-56. doi: http://dx.doi.org/10.1241/johokanri.58.53

\section{特許分科会とは}

商用オンラインデータベースの発展に伴い，サー チャー同士の相互研究のため1979年に日本オンライ ン情報検索ユーザー会（Online User Group，以下， OUG）が発足した"1)。OUGはその後，(一社）情報科 学技術協会へ吸収・再編を経て，現在は化学分科会， インターネット/ビジネス分科会，特許分科会，ラ イフサイエンス分科会の計4分科会が活動している。

特許分科会（以下，本会）は，特許調査を取り扱 う情報検索者（以下，サーチャー）の知識・技術研 鑽を主たる目的に実務的な活動を行う研究会であ る。参加者の所属は，企業・企業調査会社の知財関 係者，調査会社，特許事務所の情報調査部門や知財 部等，業種もさまざまである。また，例会もすでに 370回を超え30年以上も活動を続けている。さらに 2002年に情報科学技術協会より発行された「ひとり
でできる特許調査一特許の仕組みと情報検索虎の巻」 (絶版) は，本会が企画・執筆に携わったことなど月 例会を超えた活動も行っている2)，3)。

\section{本会の方針}

本会は，ギブ・アンド・テイクをモットーとし， 自分たちの知りたいことを参加者間で情報交換する ことを主たる目的にしている。本会は，約十数年前 より主査を含む幹事10名程度の幹事会により運営し ており，各幹事は，年間1つ以上，自分の関心事をテー マに月例会を主催している。また，遠方の会員にも 考慮し，現在はグループウェア（図1）を使い会員間 の情報交換を行っている。

\section{活動内容}

本会は，8月を除き毎月第2金曜日の14時から17時

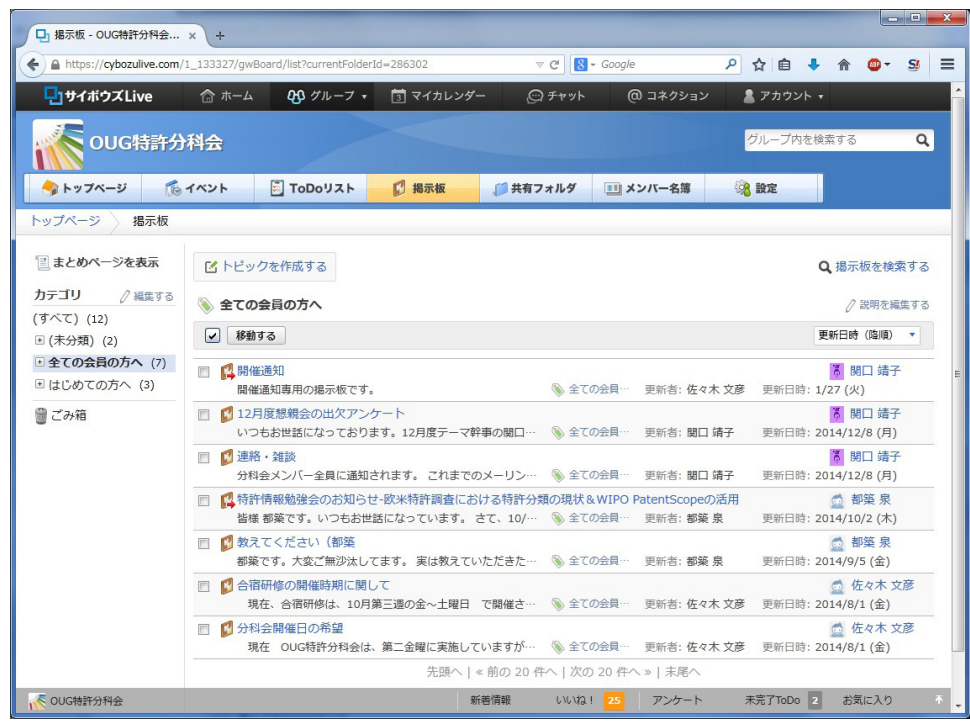

図1ＯUG特許分科会のグループウェア掲示板 
に東京で開催している。活動は，主に検索演習，講 演会と実習等である。

検索演習は，先行技術文献調査，無効化資料調査， 侵害予防調査など一般的な特許調査に加え特許分析 なども行っている。課題は，2～3時間程度で行え ることを念頭に作成している。業種がさまざまなの で誰もがわかるテーマを選定することが一苦労であ る。最近では，特許庁の調査結果をもとに，検索式 の批評演習を含めた無効化資料調査が多くなってい る。そのほか，実際に売られている商品を特許的に 解析し侵害予防調査をすることや新聞記事から特許 技術情報を調査することなども行っている。

講演会は，会員の関心事（たとえば，東南アジア の特許調査，無料特許調査 $D B$ ，新規の特許調査 $D B$ な ど）に関して，その分野の第一人者やベンダーを招 き講演していただいている。最近では，元大阪工業 大学の都築泉氏，アスタミューゼ(株) の永井歩氏， 日本技術貿易（株）の中根寿浩氏，また過去には検索 競技大会上位者や，特許庁審査官にも講演をしてい ただいた。

実習は，新人教育に関して，CPC (Cooperative Patent Classification；共同特許分類）の対応につい て，報告書の書き方や検索キーワードの上手な選択 など，会員が講師となり議論を通じ理解を深めるこ とを行った。
表1は，この1年の月例会の活動内容である。各回 の詳細や過去の内容は，情報科学技術協会のWebサ イトに議事録が掲載されているので，ぜひご覧いた だきたい2)。

表1にも記載したが，年1回（2014年度は10月）に 関東近県にて合宿を行っている。合宿は，通常の金 曜日午後十土曜日午前中の1泊2日で検索演習を中心 に直接テーマに関係のない身近な疑問，普段の例会 では時間切れになってしまう話題などについて，じっ くり議論を行っている。ちなみに日帰りも可能であ る(図2)。

\section{参加のきっかけ}

調査を始めて10年近く経ち，気がつけば社内サー チャーでは経験年数が一番長く，常に教える立場と なった。そこでこれからの自己成長には外部へ学び に行く必要があると考えたことが私が本会に参加し たきっかけだった。2009年より情報収集と自己研鑽 のためにOUGへ参加し，当時あまり得意でなかった 特許調査の勉強に取り組み始めた。

当時の業務は，化学系かつ侵害予防調査が中心で あったため，CAS (Chemical Abstracts Service) 系や DWPI（Derwent World Patents Index）での調査が主 であまり国内の特許調査はしてこなかった。そのた め，参加当初の検索演習では，無効化資料調査など

表1２014年の例会開催内容一覧

\begin{tabular}{|c|c|c|c|}
\hline 会期 & 回数 & テーマ & 内容 \\
\hline 2014 年 3 月 & 366 & 実習 & 言葉を用いた検索式の作り方 \\
\hline 2014 年 4 月 & 367 & 検索演習 & 検索批評演習（無効化資料調査） \\
\hline 2014 年 5 月 & 368 & 講演会 & $\begin{array}{l}\text { 元大阪工業大学 准教授 都築 泉 } \\
\text { 生講演会 }\end{array}$ \\
\hline 2014 年 6 月 & 369 & 実習 & 報告書作成について，再考しよう \\
\hline 2014 年 7 月 & 370 & 検索演習 & 検索批評演習（無効化資料調査） \\
\hline 2014 年 9 月 & 371 & 講演会 & $\begin{array}{l}\text { 日本技術貿易株式会社 中根氏 } \\
\text { 「ASEAN 取新知財状況」 }\end{array}$ \\
\hline 2014 年 10 月 & 372 & 検索演習 & 検索批評演習（1 泊 2 日の合宿） \\
\hline 2014 年 11 月 & 373 & 検索演習 & $\begin{array}{l}\text { 検索競技大会の問題を解いてみ } \\
\text { よう 機械編 }\end{array}$ \\
\hline 2014 年 12 月 & 374 & 講演会 & $\begin{array}{l}\text { アスタミューゼ株式会社 永井氏 } \\
\text { 「『異分野成長市場』『有望ベン } \\
\text { チャ一企業』をフックにした特許 } \\
\text { 検索」 }\end{array}$ \\
\hline 2015 年 1 月 & 375 & 実習 & 検索式のチェックポイント \\
\hline 2015 年 2 月 & 376 & 検索演習 & 検索批評演習（無効化資料調査） \\
\hline
\end{tabular}




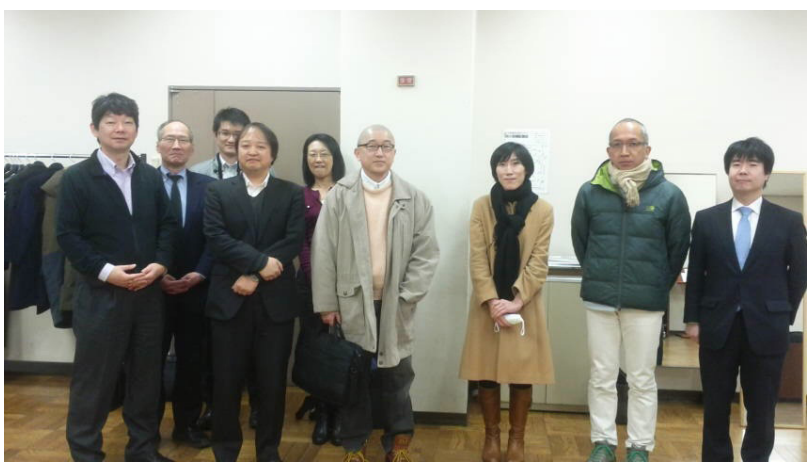

図2 2015年2月例会 出席者の集合写真

の自分で特許性を考慮して検索式を立てることがあ まりできず，ほかの皆さんの回答を見て大いに感心 していたことを今でも覚えている。その後，2011年 より幹事の末席に加えていただき，2013年に副主査， 2014年に主査を務めるに至つた。

\section{活動から得たものと今後の活動}

本会へ参加し得たものは、サーチャーとしても社 会人としても人間としても非常に多いのだが，その 中でも特に大きな4つに関して記載する。

第1は社外の人脈が広がったことである。それまで 仕事関係で話をする機会が多かったのはベンダーの 方が主流だったが，知財関係者，調査会社や競合会 社も含めた企業のサーチャーなど幅広い方と知り合 いになれた。業界の裏話，現在の関心事や課題など 同じ仕事をしているからこそわかる，共通した話題 を相談し合える仲間ができた。

第2に，特許調査の極意が学べたこと，すなわち何 をどう調べるのか，すなわちどこにゴールを置いて 調べるのか，そのためには何をすればよいのか，何 に注意をすればよいのか，会員の皆さんの発言が非 常に勉強になった。井の中の蛙大海を知らずとはよ く言ったもので，社内だけではなかなか気づかない ことが学べた。これらは，多くの諸先輩方はもちろ んだが，最近調査を始めた方の話にもいろいろな気
づきがあり非常に勉強になる。私事であるが，本会 で得られた知識をもとに社内教育を行い，部下とと もに検索競技大会2014でゴールド認定をいただくこ とができた。

第3は，合宿や例会後の雑談が非常に有意義なこと である。合宿時は，特に昼の部に加え夜の部（懇親会） では，サーチャーの未来，調査の裏話，会社の愚痴 など同じ仕事ならではのさまざまな話題の対話時間 が非常に役立つ。

第4は，幹事になって課題の問題を作成すること で，調査にはどんなことに注意していくのかが勉強 になったこと，さらに社内の教育に非常に役に立っ たことである。こんなことに気づいて欲しいという ことや，間違いやすい分類の使い方などを含め，単 なる演習ではなく，目的のある問題を考えるためそ のまま社内教育に生かすことができた。

今後は，自己研鑽に加え，諸先輩方がわれわれに 与えてくれたものを新たな会員と共有することで会 全体のレベルアップを図っていきたい。現在，出席者 が減少傾向にあるので，興味をもっていただけたら， ぜひ一度見学にいらしていただきたい。また，幹事 を引き受けるのも諸所の面で大変だが得るものも大 きいので，ぜひ立候補していただければ幸いである。

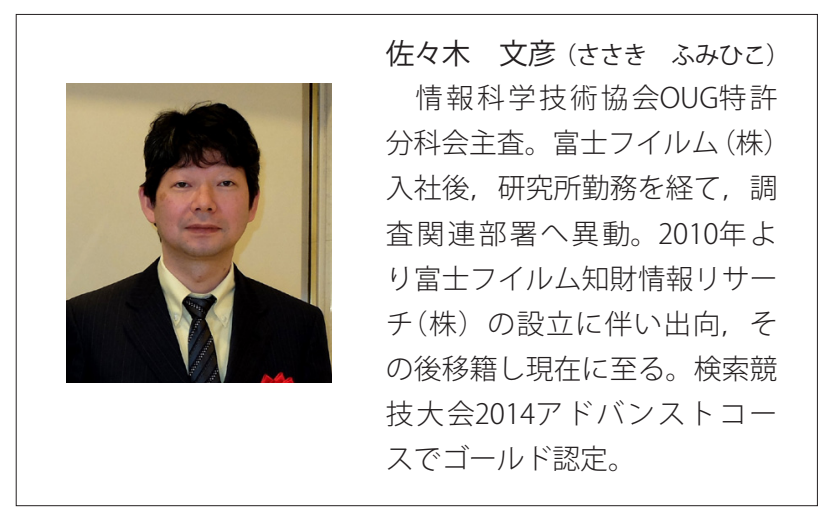




\section{参考文献}

1）情報科学技術協会. “協会のあゆみ”. 一般社団法人情報科学技術協会. http://www.infosta.or.jp/history/， (accessed 2015-2-25).

2） OUG特許分科会. “OUG特許分科会のご案内”. 一般社団法人OUG特許分科会. http://www.infosta.or.jp/pat/ index.htm, (accessed 2015-2-25).

3）関口靖子, 馬場淳子, 越智泰子. 出版委員会とOUG特許分科会の活動成果と今後の課題「ひとりでできる特 許調査」出版にあたって. INFOSTAシンポジウム予稿集. 2002, vol. 2002, p. 13-17. 